\title{
Coal-bearing strata sequence stratigraphy of Paleogene Meihe Formation, Meihe Basin, NE China
}

\author{
Yueyue Bai ${ }^{1}$ Qingtian $\mathrm{Lü}^{1} \cdot{\text { Zhaojun } \mathrm{Liu}^{2} \cdot \text { Pingchang Sun }^{2} \cdot \text { Rong Liu }}^{2} \cdot$ \\ Shuqing $\mathrm{Yao}^{2}$
}

Received: 13 April 2020/Revised: 29 July 2020/Accepted: 3 November 2020/Published online: 4 December 2020

(C) The Author(s) 2020

\begin{abstract}
The Meihe Basin is an important Paleogene coal-bearing basin located in the Dunhua-Mishan Fault Zone, northeastern China. Based on a comprehensive study of well logs, seismic profiles, cores and rock geochemical properties, the coal distribution, paleoenvironment evolution within a sequence stratigraphic framework and the accumulation model to explain how coal seams developed in small fault basin were discussed in detail. Three-third-order sequences were identified in the Paleogene Meihe Formation of Meihe Basin and the two coal-bearing sequences are the Lower Coalbearing Member of Sequence I and the Upper Coal-bearing Member of Sequence III. All three types of system tracts are developed in both sequences, i.e., the lowstand systems tract (LST), the transgressive systems tract (TST), and the highstand systems tract (HST). In LST of Sequence I, fan delta plain marsh is the main coal accumulating environment where coal seams are thin, discontinuous and therefore uneconomic for mining, and it is the same with all coal seams developed in Sequence III. While in TST and HST of Sequence I, lake swamp is the main sedimentary environment where coal seams are thick, continuous, widely distributed, and thus economically attractive for mining. In the study area, the nice thick economical coal seams are usually developed in an ideal stable depositional environment where organic matter accommodation space grows at a balanced rate with peat, in other words, free of sediment input or channel migration. The key findings of this study could provide guidance for the exploration of coal seams in the Meihe Basin and other similar basins.
\end{abstract}

Keywords Coal seam $\cdot$ Sequence stratigraphy $\cdot$ Fan delta $\cdot$ Swamp $\cdot$ Meihe Basin

\section{Introduction}

The occurrence and distribution of coals is primarily controlled by base level changes, but also affected by accommodation space, sediment supply, peat-accumulation rate and climate changes (Flint et al. 1995; Diessel et al. 2000; Buillit et al. 2002; Opluštil et al. 2013). Ryer

Yueyue Bai

yueying0210@126.com

1 SinoProbe-China Deep Exploration Center, Chinese Academy of Geological Sciences, Beijng 100037, China

2 Key Laboratory for Oil Shale and Coexisting Minerals Mineralization and Exploration and Exploitation, Jilin University, Changchun 130061, China
(1981, 2009) claimed that the thickest and most widely distributed coal seams in delta sand bodies accumulated mainly near the maximum flooding surface. Bohacs and Suter (1997) found that thick and widely-distributed coal seams are usually deposited in the transgression systems tract (TST) typical of, rising accommodation space. Diessel (1992, 2007) investigated different coal seams developed in eight countries and argued that the economically minable coal seams are mostly developed in the middle stages of the transgression systems tract (TST) and the high stand systems tract (HST). Besides, Shao et al. (2003a, b) concluded that the accumulation of economically minable coal seams are probably related to the maximum flooding surface of the TST. However, the subject of all the research work conducted above was marine basins, while most of the coal-bearing basins in China are non-marine basins 
with coal seams developed mainly in the river-delta-lake sedimentary system. Non-marine basins are mostly small in-scale featuring close and multiple provenances, and sometimes, abrupt slopes. They are prone to be influenced by paleoclimate and paleostructure. Coal seams in nonmarine basins are usually characterized with variable thickness and distribution in different system tracts (Liu et al. 2002; Shanley and McCabe 1994).

The Meihe Basin is an important coal-bearing fault basin in northeastern China, and coal is developed predominantly in the fan delta and swamp environments. The 12 th coal seam in the Lower Coal-Bearing Member (LCM) is most economically attractive for mining ( $\mathrm{Hu}$ et al. 1996a; Wang et al. 2008). Wu et al. (2008) and $\mathrm{Hu}$ et al. (1996b) claimed that paleoenvironment is one of the controlling factors for the occurrence and distribution of Meihe Basin coal seams. The coals were deposited mostly in the peat mire between the fan delta body and the swamp of the fan delta plains and in the silty swamps of lakes. Bai et al. (2014, 2017) argued that the Meihe coals mainly developed in the fan delta plain marsh and lake swamp environments where type $\mathrm{II}_{2}$ organic matter derived most likely from terrigenous higher plants were prevalent. Furthermore, it was deemed that coal seams accumulated primarily in reducing freshwater environments.

Most of the aforementioned studies focused largely on the depositional environment of coal seams in the Meihe Basin and discussed the factors affecting their accumulation. Yet the sequence stratigraphy of coal-bearing strata has not been studied. This paper presented a comprehensive study approach with respect to sequence stratigraphy, well logs, geochemistry and sedimentology of the Paleogene Meihe Formation, and further discussed the coal distribution and paleoenvironment evolution in detail within a sequence stratigraphic framework. Finally an accumulation model was established to explain how coal seams developed in small fault basins.

\section{Geological setting}

\subsection{Tectonic setting}

The Meihe Basin is a Paleogene fault basin in the DunhuaMishan Fault zone with coals and oil shales in coexistence (Bai et al. 2014, 2017). The tectonic evolution of the Meihe Basin consists of three stages, the early basement deformation stage, the synsedimentary deformation stage and recent structural deformation stage. The pre-existing basement deformation stage started in the late Mesozoic and the stretching in the late Yanshan movement controlled the deposition of Cretaceous sediments. The synsedimentary deformation stage of Meihe Basin occurred in the early
Paleogene and the extensional faults $F_{1}$ and $F_{2}$ developed at the rim of the basin directly controlled the sedimentary thickness and distribution of coals and shales in the Meihe formation. After the synsedimentary deformation, basin filling ended and structural deformation developed. (Wang et al. 2008; Liu et al. 2015; Bai et al. 2017) (Fig. 1).

\subsection{Lithostratigraphy}

The basin fill of the Paleogenen Meihe Formation is up to $1000 \mathrm{~m}$ thick and overlies various basement units, including Cretaceous sedimentary rocks and Presinian strata. The Meihe Formation consists of five members. From bottom to top, they are the Conglomerate Member, the Lower Coal-bearing Member (LCM), the Oil Shalebearing Member (the Mudstone Member), the Upper Coalbearing Member (UCM), and the Green Rock Member (Wu et al. 2008; Liu et al. 2015). The Lower and the Upper Coal-bearing members (LCM and UCM) were studied and discussed in this article.

\subsection{Sedimentary facies}

A lot of researchers (Bai et al. 2014, 2017; Wang 2012; Liu et al. 2015) have studied the sedimentary evolution and features about the Meihe Basin. They found that the Conglomerate Member mainly consists of alluvial fan and fan delta sediments of conglomerate, sandy conglomerate and coarse sandstone interbedded with red mudstone; the Mudstone Member mainly consists of shallow lake and semi-deep to deep lake sediments. Due to the existence of a Quaternary cover of up to $10 \mathrm{~m}$ thickness, few core samples have been collected from the Green Rock Member, hence inadequate information for evaluation (Wang 2012; Yao 2012; Liu et al. 2015; Bai et al. 2017).

The target strata, LCM and the UCM, consist primarily of lake and fan delta sediments (note that the 12th coal seam of the highest commercial value is in the LCM). In both strata identified sedimentary facies include the subfacies of fan delta plain and fan delta front, microfacies of distributary channel with a scour-and-fill structure, distributary interchannel with thin coal seams and carbonaceous mudstone, as well as the underwater distributuary channel with light grey and green grey sandstone. When it comes to lacustrine environments, specifically, identified sedimentary facies include shallow lake with greenish grey siltstone and mudstone and lake swamp with black coal, carbonaceous mudstone and greenish grey mudstone. The characteristics of different microfacies identified in LCM and UCM are detailed and compared in Table 1 and Fig. 2 (Bai et al. 2014, 2017). 


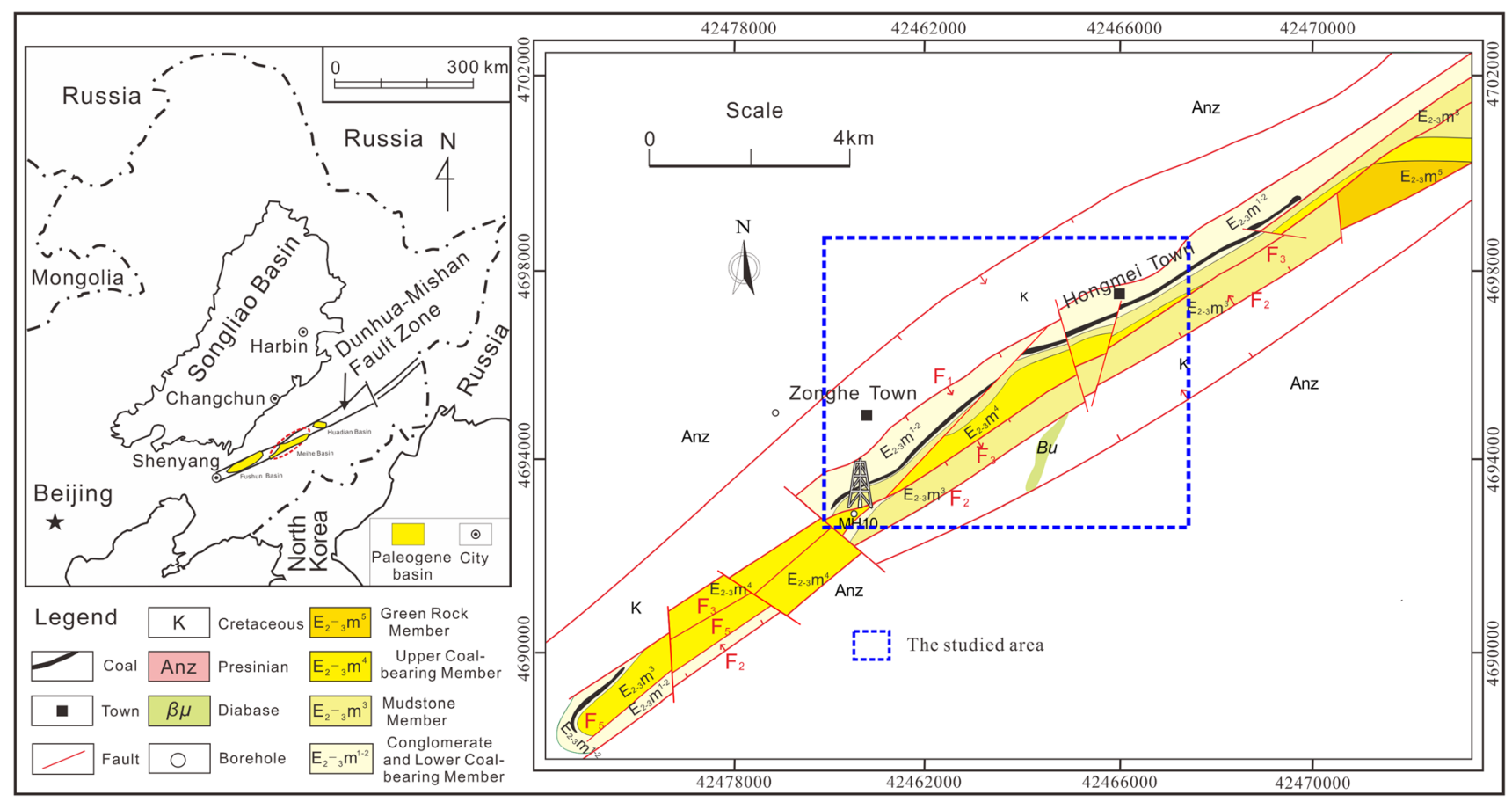

Fig. 1 Geological map of the Meihe Basin

\section{Sampling and methods}

Unweathered samples of gray and brown siltstone, mudstone, oil shale and coal were collected from well MH2011-10. For those used in this study, 8 samples are from the LCM at depths of 657.9-754.4 m and 32 are from the UCM at depths of 52.8-546.6 m (Fig. 3).

The trace element concentration was measured at the National Geological Experiment Center of China using a Thermo Scientific ELEMENT high-resolution ICP-MS following the Chinese Standard GB/T 14506.30-2010. The total organic carbon (TOC) content was tested and analyzed following the Chinese Standard GB/T 19145-2003 at the Changchun Mineral Resources Supervision and Inspection Center using a LECO CS-230 instrument.

Drill core observation, well log analysis, seismic interpretation and geochemistry study were previously conducted (Wang 2012; Yao 2012) to identify the sequence stratigraphy of the study area. Combining the single-factor approach and the comprehensive multifactor mapping method (proposed by Feng 2004), the palaeogeography and lithofacies of each system tract can be rebuilt. Base geological information, in other words, the single factors such as the water depth, energy level, stratum thickness, rock type, structure, mineral composition and rock color were first evaluated because they could independently and quantitatively reflect the sedimentary environments of the study area. Based on this, statistical analyses were performed with each single factor accounted for and weighted generating corresponding contour maps that cater to conclusive judgment. At last, the palaeogeography and lithofacies can be rebuilt quantitatively.

\section{Results}

\subsection{Sequence boundaries and system tracts}

\subsubsection{Sequence boundaries}

Two sequence boundaries have been identified-one is between the LCM and the Mudstone Member (marked "te1" in the seismic profile) (Fig. 3), and the other is between the Mudstone Member and the UCM (marked "te2" in the seismic profile) (Fig. 4). These three members constitute a third-order sequence where LCM corresponds to Sequence I (LCM) and UCM corresponds to Sequence III (Fig. 3).

(1) Identification of lithology

Unconformity, sedimentary hiatus, exposure, and stream channel incision are classic lithology identification marks (Powell 1875; Cross 1988; Adabi et al. 2016). Three completely different depositional systems develop in the Meihe Formation and their lithological association changed drastically from bottom to top: (i) the Conglomerate Member and LCM primarily contain fan delta sediments and thick coal seams deposited in lake swamps; (ii) the 
Table 1 Characteristics of the main sediments of coal-bearing layers (Bai et al., 2014a, Bai et al., 2017; Liu et al., 2015; Bai et al., 2017)

\begin{tabular}{|c|c|c|c|c|c|c|c|c|c|}
\hline \multicolumn{3}{|c|}{ Sedimentary Face } & \multirow[t]{2}{*}{ Lithology } & \multicolumn{5}{|c|}{ Grading analysis } & \multirow{2}{*}{$\begin{array}{l}\text { Well-long } \\
\text { analysis }\end{array}$} \\
\hline Facies & Subfacies & Microfacies & & Histogram & $\begin{array}{l}\text { Standard } \\
\text { deviation }\end{array}$ & Skewness & Kurtosis & $\begin{array}{l}\text { Probability } \\
\text { cumulative } \\
\text { curve }\end{array}$ & \\
\hline \multirow[t]{7}{*}{$\begin{array}{l}\text { Fan } \\
\text { delta }\end{array}$} & \multirow[t]{3}{*}{$\begin{array}{c}\text { Fan delta } \\
\text { plain }\end{array}$} & $\begin{array}{l}\text { Distributary } \\
\text { channel }\end{array}$ & $\begin{array}{l}\text { The distributary channel mainly } \\
\text { consists of red, light grey and } \\
\text { mingled conglomerate, sandy } \\
\text { conglomerate and pebbly } \\
\text { sandstone with poor structure } \\
\text { maturity and component } \\
\text { maturity. The erosional surface, } \\
\text { trough cross bedding and normal } \\
\text { graded bedding can be } \\
\text { seen(Fig. } 2 \mathrm{a}, \mathrm{b}) \text {. }\end{array}$ & $\begin{array}{r}\text { Double } \\
\text { peak }\end{array}$ & 0.72 & -0.13 & $0.91-1.03$ & $\begin{array}{l}\text { Mainly consists } \\
\text { of two-stage } \\
\text { curves, one- } \\
\text { stage and } \\
\text { three-stage } \\
\text { curves also } \\
\text { exist. }\end{array}$ & $\begin{array}{l}\text { Medium to } \\
\text { high- } \\
\text { amplitude } \\
\text { bell shape } \\
\text { and } \\
\text { serrated } \\
\text { cylinder } \\
\text { shape. }\end{array}$ \\
\hline & & $\begin{array}{l}\text { Distributary } \\
\text { interchannel }\end{array}$ & \multicolumn{6}{|c|}{ The interchannel mainly consists of red and dark grey siltstone and mudstone with the interbedded fine sandstone. } & $\begin{array}{l}\text { Medium- } \\
\text { amplitude } \\
\text { serrated } \\
\text { shape }\end{array}$ \\
\hline & & $\begin{array}{l}\text { Fan delta plain } \\
\text { marsh }\end{array}$ & \multicolumn{6}{|c|}{$\begin{array}{l}\text { The sediments are mainly dark coal and carbonaceous mudstone with interbedded sandstone. It is the main coal } \\
\text { accumulation environment of fan delta. }\end{array}$} & $\begin{array}{l}\text { Low to } \\
\text { medium- } \\
\text { amplitude } \\
\text { box shape } \\
\text { and bell } \\
\text { shape }\end{array}$ \\
\hline & \multirow[t]{4}{*}{$\begin{array}{l}\text { Fan delta } \\
\text { front }\end{array}$} & $\begin{array}{l}\text { Underwater } \\
\text { distributary } \\
\text { channel }\end{array}$ & $\begin{array}{l}\text { The underwater distributary channel } \\
\text { mainly consists of light grey and } \\
\text { grey coarse to fine sandstones. } \\
\text { The climbing ripple bedding, } \\
\text { deformed bedding and } \\
\text { bioturbation can be seen in the } \\
\text { core(Fig. } 2 \text { c,d,e). }\end{array}$ & $\begin{array}{l}\text { Single } \\
\text { peak }\end{array}$ & $\begin{array}{l}0.77 \text { (in } \\
\text { average) }\end{array}$ & 0 & $0.8-1.2$ & $\begin{array}{l}\text { Mainly are two- } \\
\text { stage and } \\
\text { three-stage } \\
\text { curves. }\end{array}$ & $\begin{array}{l}\text { Medium to } \\
\text { high- } \\
\text { amplitude } \\
\text { box shape } \\
\text { and bell } \\
\text { shape. }\end{array}$ \\
\hline & & $\begin{array}{l}\text { Underwater } \\
\text { distributary } \\
\text { interchannel }\end{array}$ & $\begin{array}{l}\text { The interchannel mainly consists of } \\
\text { dark grey siltstone and mudstone } \\
\text { with large amount of charcoals in } \\
\text { it. }\end{array}$ & $\begin{array}{l}\text { Single } \\
\text { peak }\end{array}$ & $\begin{array}{l}0.49 \text { (in } \\
\text { average) }\end{array}$ & $\begin{array}{l}-0.13 \text { (in } \\
\quad \text { average) }\end{array}$ & $\begin{array}{l}1.03 \text { (in } \\
\text { average) }\end{array}$ & $\begin{array}{l}\text { Mainly are one- } \\
\text { stage curves. }\end{array}$ & $\begin{array}{c}\text { Serrated line } \\
\text { shape. }\end{array}$ \\
\hline & & Mouth bar & $\begin{array}{l}\text { Coardening upward as a whole, the } \\
\text { lower part consists of dark gray } \\
\text { mudstone and siltstone, the upper } \\
\text { part consists of medium to fine } \\
\text { sandstones, bioturbation and } \\
\text { deformed bedding can be seen in } \\
\text { the core (Fig. } 2 \mathrm{f} \text { ). }\end{array}$ & $\begin{array}{l}\text { Single } \\
\text { peak }\end{array}$ & 0.45 (average) & $\begin{array}{l}-0.05 \text { (in } \\
\quad \text { avearge) }\end{array}$ & $\begin{array}{l}1.12 \text { (in } \\
\quad \text { average) }\end{array}$ & $\begin{array}{l}\text { Mainly are two- } \\
\text { stage and } \\
\text { double-leap } \\
\text { three-stage } \\
\text { curves. }\end{array}$ & $\begin{array}{l}\text { Low to } \\
\text { medium- } \\
\text { amplitude } \\
\text { serrated } \\
\text { funnel } \\
\text { shape. }\end{array}$ \\
\hline & & Sheet sand & $\begin{array}{l}\text { Gray fine sandstone and siltstone } \\
\text { interbedded with mudstone are } \\
\text { the main sediments, the climbing } \\
\text { ripple bedding, current bedding } \\
\text { and bimodal cross-bedding are } \\
\text { common (Fig. } 2 \mathrm{~g}, \mathrm{~h} \text { ). }\end{array}$ & $\begin{array}{l}\text { Single } \\
\text { peak }\end{array}$ & $\begin{array}{l}0.42 \text { (in } \\
\text { average) }\end{array}$ & $\begin{array}{l}-0.09 \text { (in } \\
\quad \text { average) }\end{array}$ & $\begin{array}{l}1.07 \text { (in } \\
\text { average) }\end{array}$ & $\begin{array}{l}\text { Mainly are two- } \\
\text { stage curves } \\
\text { with large } \\
\text { slope in the } \\
\text { curves of } \\
\text { jump } \\
\text { components. }\end{array}$ & $\begin{array}{l}\text { Low to } \\
\text { medium- } \\
\text { amplitude } \\
\text { serrated } \\
\text { finger } \\
\text { shape. }\end{array}$ \\
\hline Lake & \multicolumn{2}{|c|}{ Shallow lake } & \multicolumn{6}{|c|}{$\begin{array}{l}\text { The sediments are mainly light grey fine sandstone and siltstone, green grey siltstone and mudstone with large } \\
\text { amount of charcoals in it, the current bedding, rhythmic bedding, burrows and fossils are common(Fig. } 2 \mathrm{i}, \mathrm{j}, \mathrm{k} \text { ). }\end{array}$} & $\begin{array}{l}\text { Medium to } \\
\text { high- } \\
\text { amplitude } \\
\text { serrated } \\
\text { box shape } \\
\text { and finger } \\
\text { shape. }\end{array}$ \\
\hline & \multicolumn{2}{|c|}{ Lake swamp } & \multicolumn{6}{|c|}{$\begin{array}{l}\text { The sediments are mainly consist of thick coal seam and carbonaceous mudstone, the underlayer commonly is } \\
\text { shallow lake sediments. It is the important environment for the coal accumulation of Meihe Basin(Fig. 2l). }\end{array}$} & $\begin{array}{l}\text { Serrated line } \\
\text { shape and } \\
\text { finger } \\
\text { shape. }\end{array}$ \\
\hline
\end{tabular}




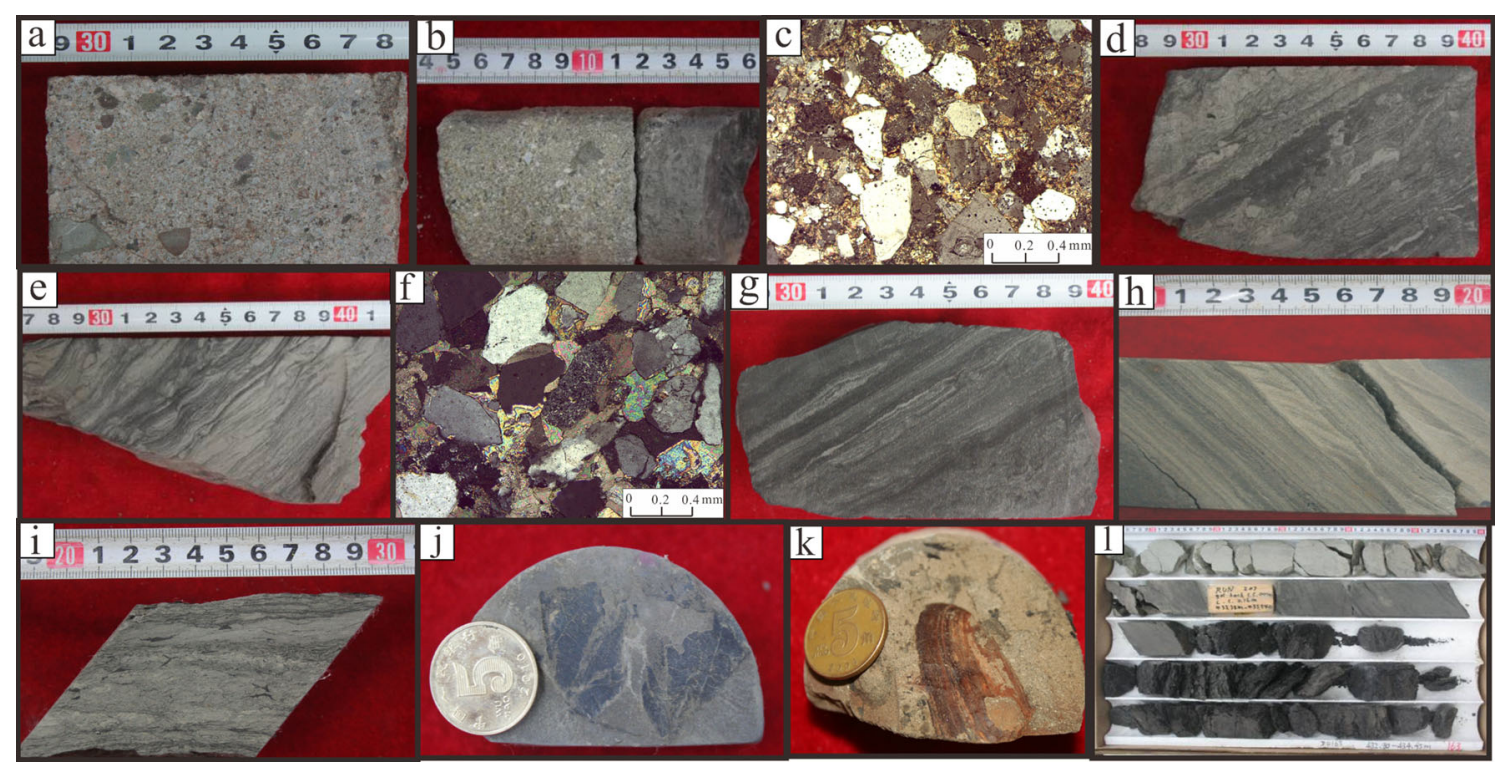

Fig. 2 Core and microscopic pictures of different sedimentary facies. a Conglomerate with poor component and textural maturity in fan delta plain, well MH2011-10, 694.40 m; b Erosional surface of fan delta front, well Mh3, $315.48 \mathrm{~m}$; c Poor-sorted medium sand stone in underwater distributary channel, well MH2011-10, 680.20 m; d Bioturbation of fan delta front, well Mh3, $525.65 \mathrm{~m}$; e Current bedding of fan delta front sheet sand, well MH2011-10, $493.80 \mathrm{~m}$; f Well-sorted fine sandstone in mouth bar, well Mh3, $642.50 \mathrm{~m}$; $\mathbf{g}$ Wavy bedding and bioturbation structures developed in sheet sand, well Mh3, $624.10 \mathrm{~m}$; h Climbing ripple bedding and current bedding in sheet sand, well Mh3, $212.90 \mathrm{~m}$; i Large amounts of charcoals developed in shallow lake, well Mh3, $560.50 \mathrm{~m}$; j Plant leaves in shallow lake, well Mh3,119.50 m; k Shell fossils in shallow lake, well Mh3, $593.50 \mathrm{~m}$; I Coals deposited in lake swamp, well Mh3, 432.80-434.95 m

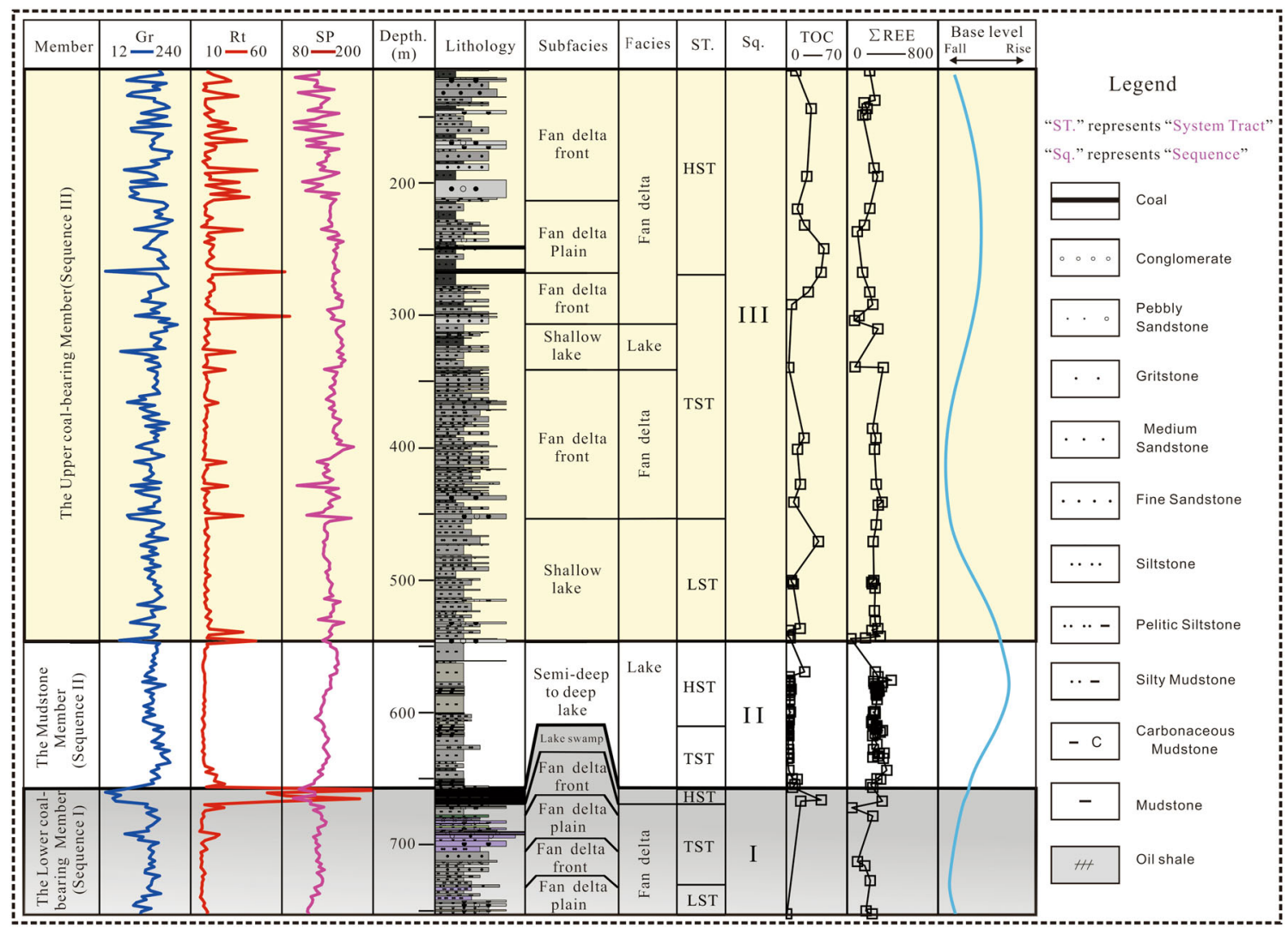

Fig. 3 Characteristics of Sequence I and Sequence III of well MH2011-10 


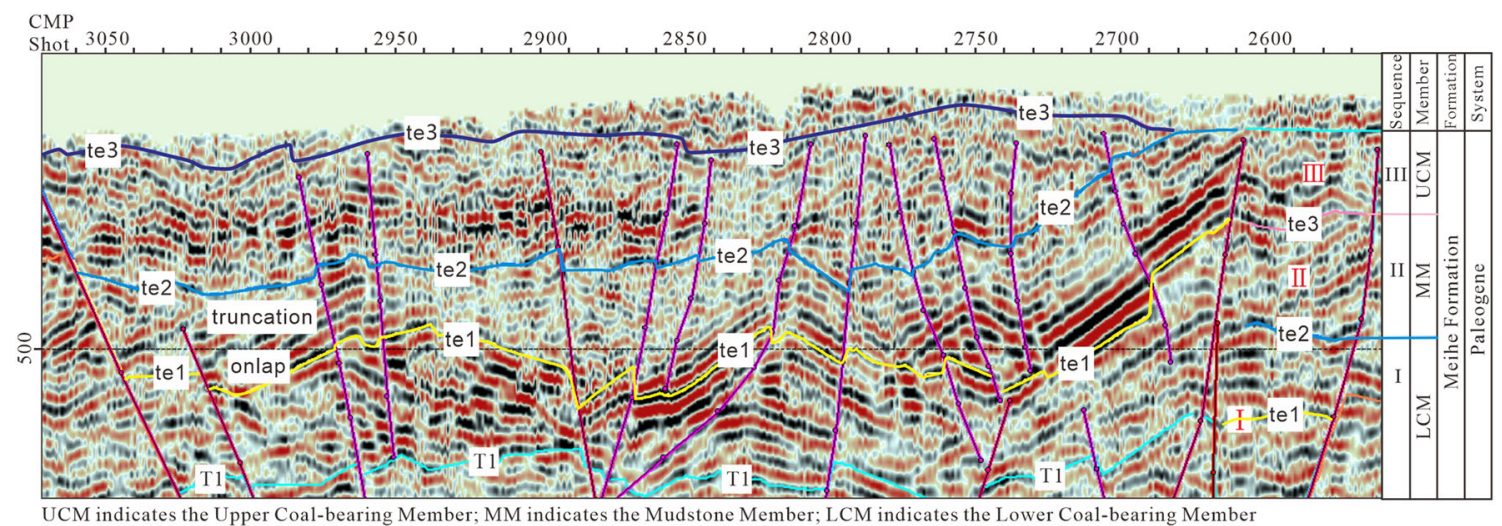

Fig. 4 Seismic cross-section of line 768 in the Meihe Basin (Wang, 2012)

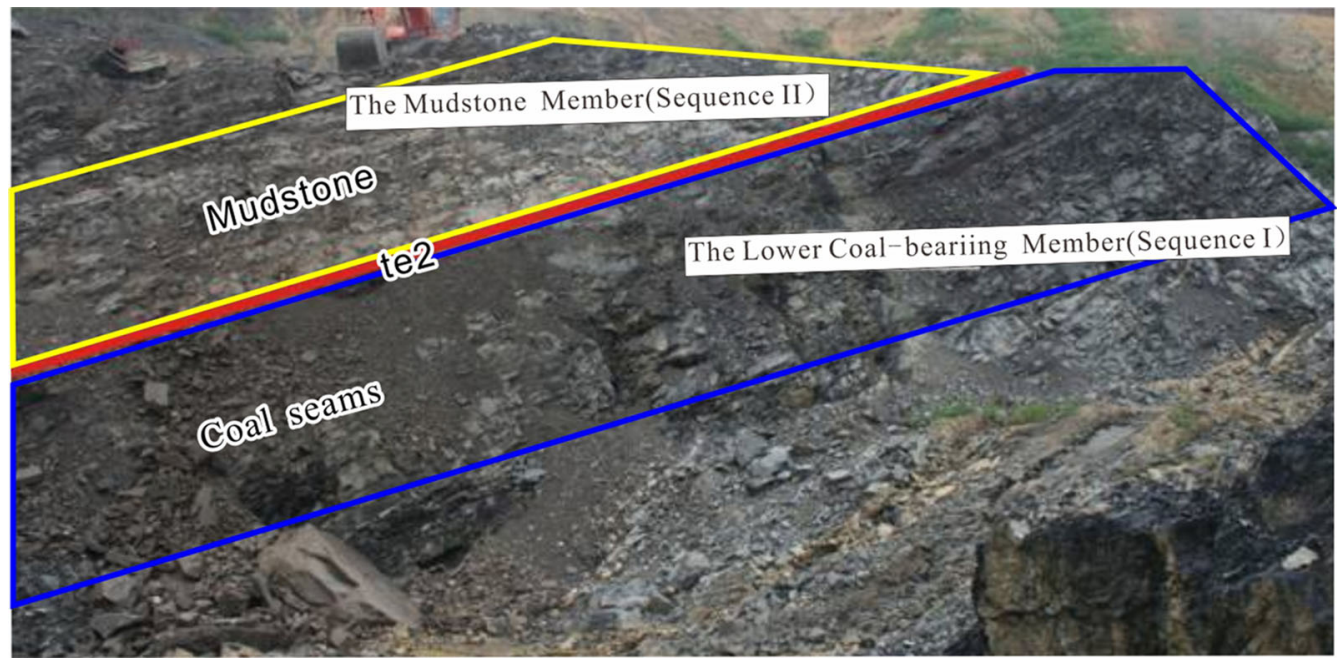

Fig. 5 Outcrop of Sequence te 2 boundary which represents the characteristics of the thick coal seams abruptly changed into thick dark mudstones

Mudstone Member consists predominantly of semideep to deep lacustrine sediments of oil shale, siltstone and mudstone; (iii) the UCM compose mainly of fan delta front and shallow lacustrine sediments. The thick coal seams in the LCM are overlain directly by the thick dark mudstones of the Mudstone Member, and this indicates a hiatus in between (Fig. 3, 5).

(2) Identification of well-log curves

The two sequence boundaries of Meihe Basin can also be easily recognized from the sudden changes of well log curves (Van et al. 1990), where up against the te 1 and te 2 boundaries, formation resistivity $\left(R_{\mathrm{t}}\right)$ increases drastically whilst gamma-ray (Gr) drops distinctively (Fig. 3).

(3) Identification of seismic profiles

In Meihe Formation, seismic reflections usually emerge and terminate in the geometry of onlap, toplap or truncation. They either truncate under or onlap over the sequence boundary (Wang 2012; Yao 2012). Onlapping can be observed in both boundaries (Fig. 4) and sequence boundary te 2 is characterized by medium to high amplitude, intermediate frequency and continuous to discontinuous reflections.

\subsubsection{Identification of system tract}

The system tracts are the sedimentary systems that formed during the same geological time. A third-order Sequence is classified as a combination of the lowstand systems tract (LST), the transgression systems tract (TST) and the high stand systems tract (HST) (Olsen 1990; Shanley 1994; Vail et al. 1991). The initial and the maximum flooding surfaces are the key differentiators for the classification as they always cause significant changes in the well logs and lithology. In well MH2011-10, two obvious and drastic 
a. Sedimentary facies and sequences stratigraphy correlation map of profile $A$

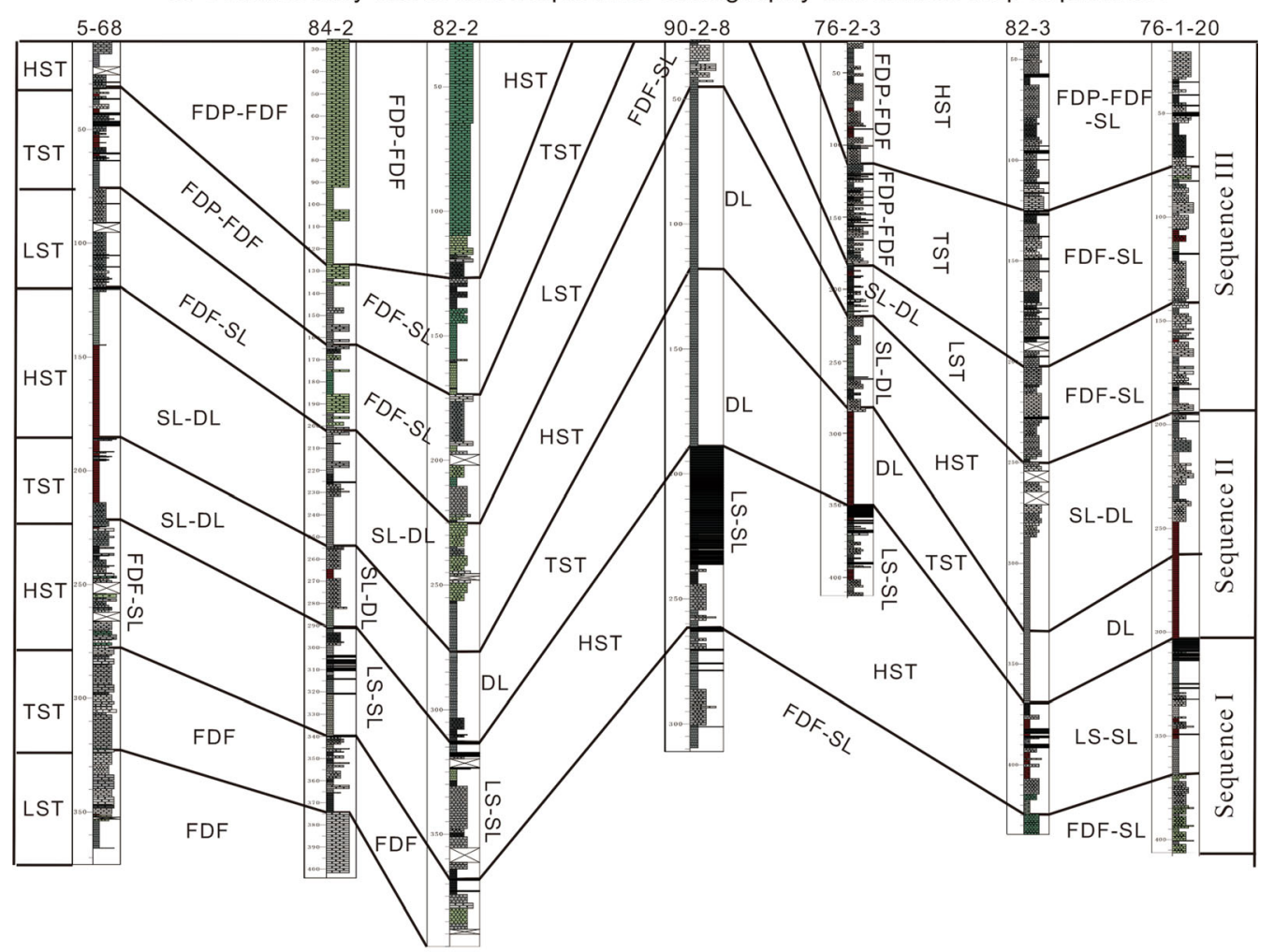

b. Sedimentary facies and sequences stratigraphy correlation map of profile B

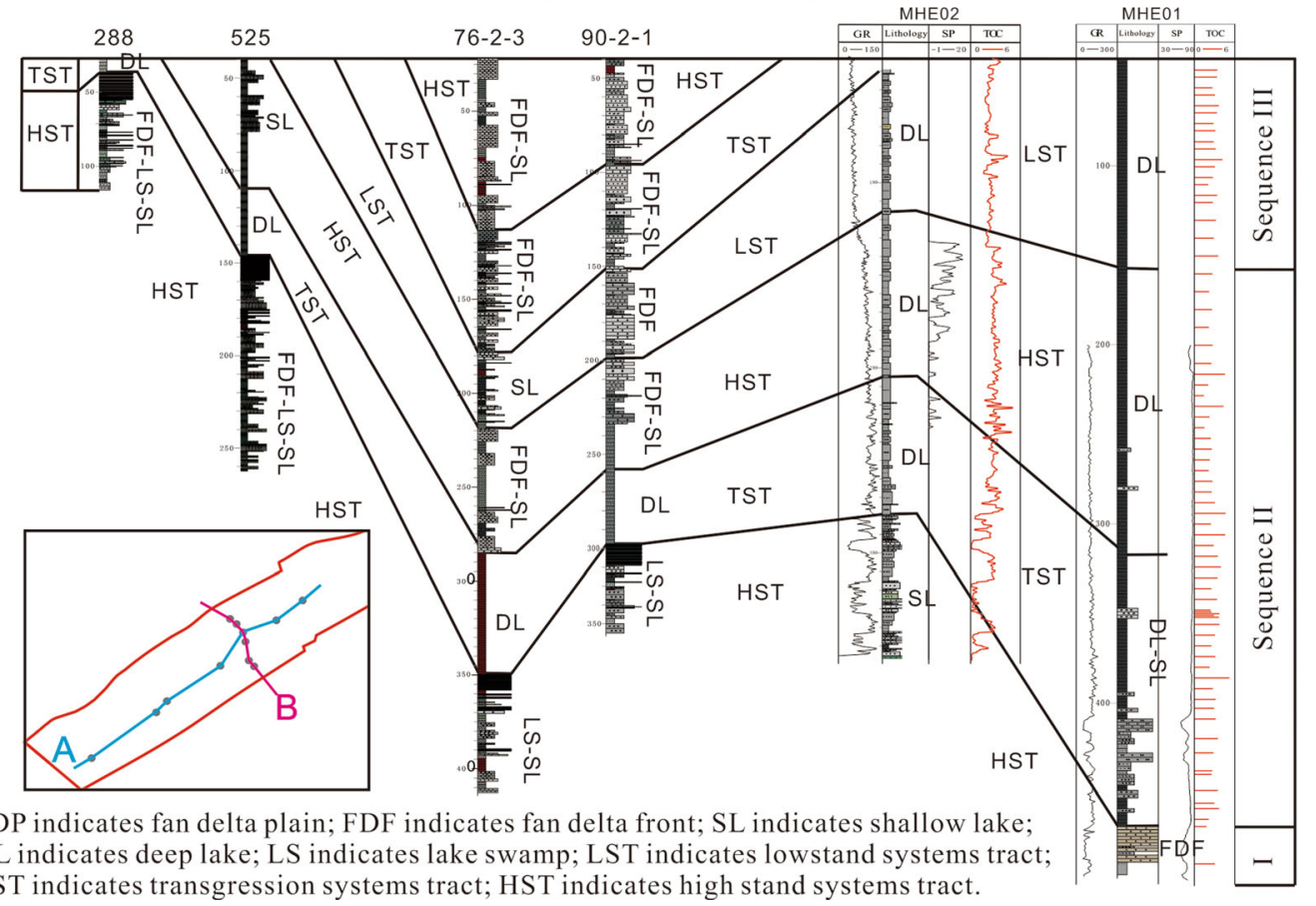

Fig. 6 Correlation maps of sedimentary facies-sequence stratigraphy of key profiles

changes in the logging curves correspond to these two surfaces. Above the maximum flooding surface are low SP, high gamma ray and high resistivity (Fig. 3). Coarse sandstone of the fan delta plain sediments is overlain by dark silty mudstone of fan delta front sediments at the first flooding surface. While at the maximum flooding surface, sandstone of fan delta front is overlain directly by coal seams of lake swamp (Sequence I) or coal or charcoal of 

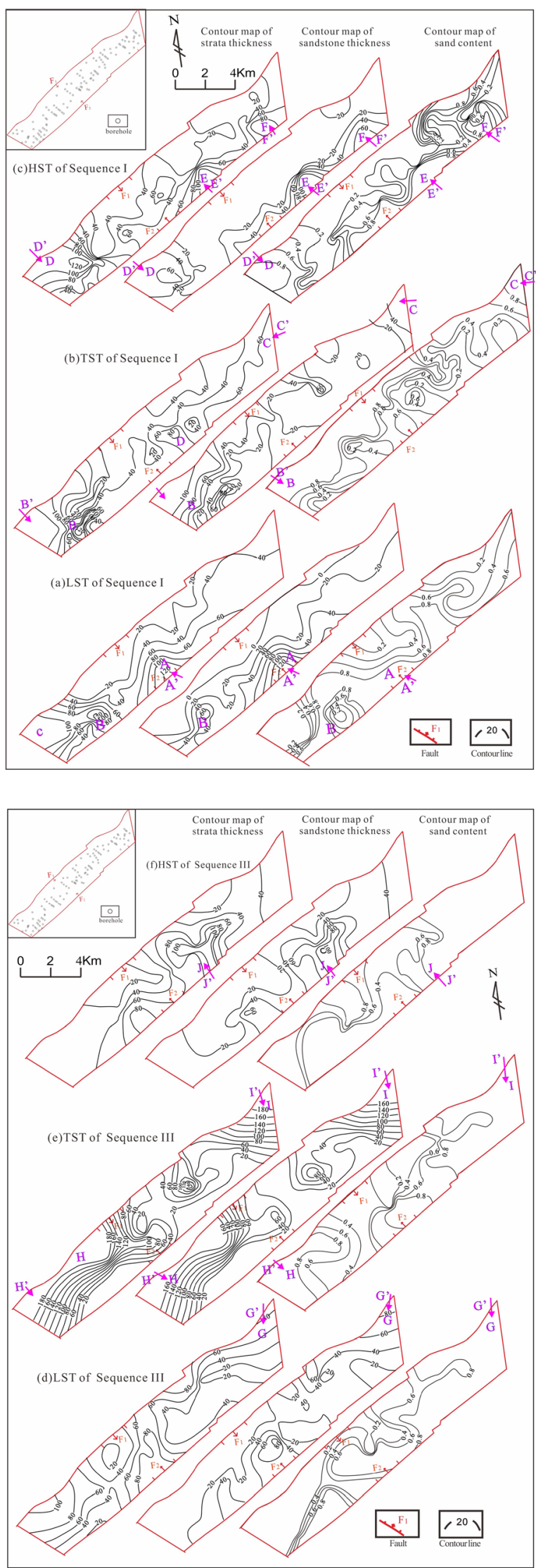

4Fig. 7 Contour maps of total stratum thickness, sandstone stratum thickness and the ratio of sand content of the LST, TST and HST in a Sequence I b Sequence III

fan delta plain marsh (Sequence III). Thereafter, LST, TST and HST are distinguished in the third-order sequence by using the two surfaces as markers.

Besides, the rare earth elements (REEs) can also be used to identify the system tracts (Tian et al. 2006), where the total REE content ( $\sum \mathrm{REE}$ ) increases from LST to TST till it reaches maximum at the maximum flooding surface and then decreases in the HST (Fig. 3).

In summary, both Sequence I (LCM) and Sequence III (UCM) contain LST, TST and HST. Due to the occurrence of a parallel unconformity between Sequence I and Sequence II, only the TST and HST are developed in Sequence II (Fig. 3).

\subsection{Sedimentary facies variation}

In this paper the paleogeography and lithofacies of each system tract in the third-order sequence were reconstructed using the single-factor analysis and the multifactor comprehensive mapping method proposed by Feng (2004). By integrating the study results of cores and environmental facies obtained from 134 wells and the stratigraphic correlations (Fig. 6) conducted for the key exploration lines, contour maps of various single-factors, i.e., strata thickness, sandstone thickness, sand content, thickness of coal seams and number of coal seams, were derived.

\subsubsection{Strata and sandstone distribution characteristics}

\section{(1) Sequence I (the LCM)}

LST (Fig. 7a) (i) The strata thickness contour map shows that the strata are thickest in the areas marked as A, B and $\mathrm{C}$, typically in a fan or leaf shape. The thinnest strata are mainly located in the northwest in the vicinity of boundary fault $F_{1}$. (ii) The sandstone thickness contour map shows that the thickest sandstones are developed in area $\mathrm{A}$, while the thinnest ones are distributed predominantly in the west. (iii) The sand content contour map shows that the strata of the highest sand content are mainly located in area A and $\mathrm{B}$, while those of the lowest sand content are near the western boundaries of the study area. From the above it is clear that area A has the highest strata thickness, sandstone thickness and sand content, indicating that direction $\mathrm{A}^{\prime}$ is the major sedimentary provenance during the deposition of LST in Sequence I.

TST (Fig. 7b) (i) The thickest strata are in the areas of B, $\mathrm{C}$ and $\mathrm{D}$, while the thinnest are distributed in the west 


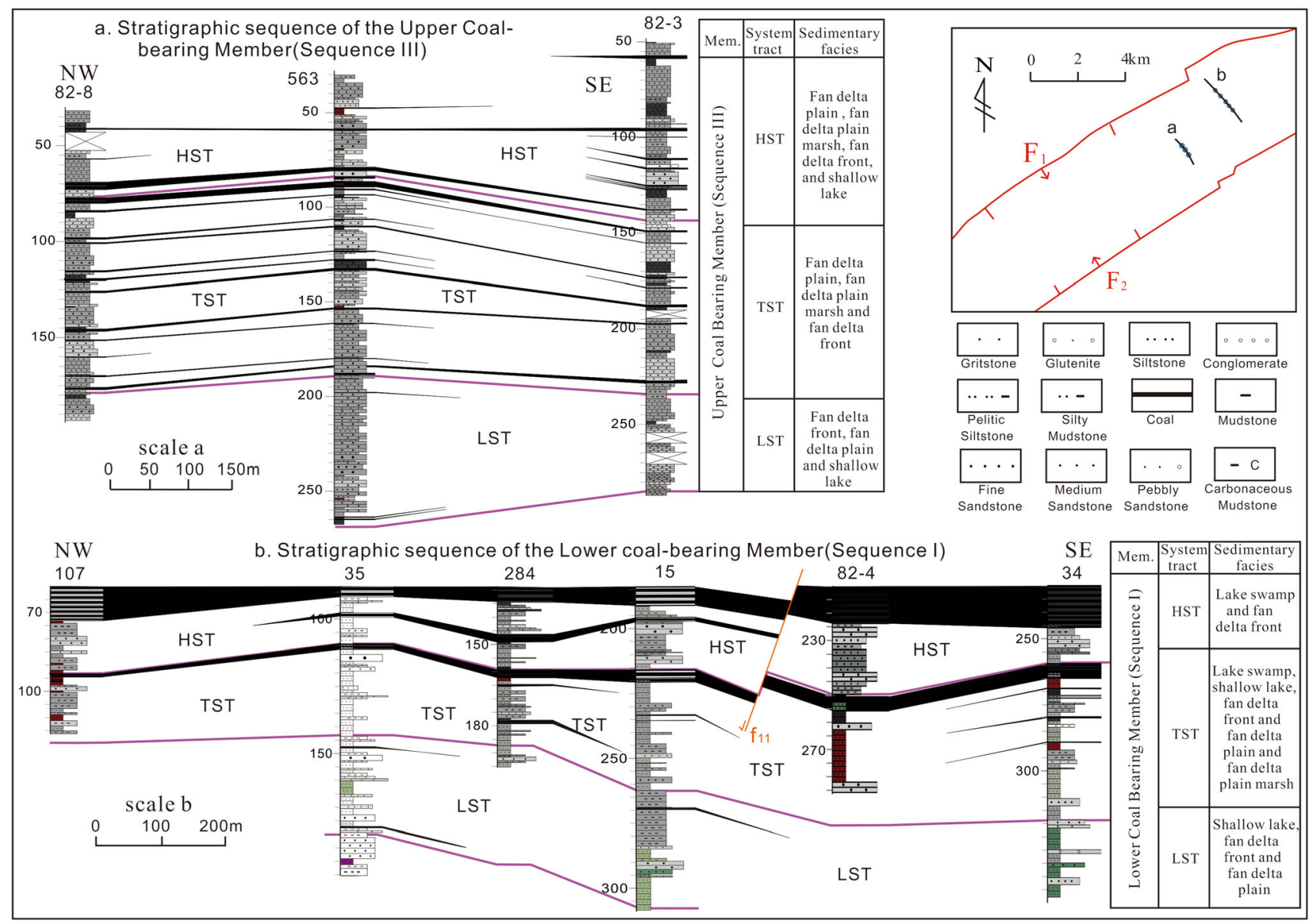

Fig. 8 Vertical changes in the coal seams and sedimentary associations of the LST, TST and HST in Sequence I and Sequence III

wedging towards south. (ii) The sandstones are thickest in area B and thinnest in the vicinity of boundary fault F2. (iii) The highest sand contents are found in area $\mathrm{C}$ at the north corner and the entire southwest including area $\mathrm{B}$, while the lowest are distributed along boundary fault $\mathrm{F}_{2}$. It can be inferred from these three maps above that there might have been one major sedimentary provenance of B' and one secondary provenance of C'.

$H S T$ (Fig. 7c) (i) The thickest strata are present in the areas of $\mathrm{D}, \mathrm{E}$ and $\mathrm{F}$, in a fan-shaped distribution, and the thinnest are clearly in the northwest. (ii) The thickest sandstones are also located in the D, E and F, while the thinnest are vastly distributed in the middle west. (iii) Sand contents are found highest again in D, E and F, and lowest in the middle west close to the boundary fault $F_{1}$. These three maps reveal that there are likely to be two sedimentary provenances for the HST of Sequence I: the primary D' and secondary E'.

\section{(2) Sequence III (the UCM)}

$L S T$ (Fig. 7d) (i) There are four areas of highest strata thickness, three on the western boundary including area $G$ and one near the eastern boundary fault $\mathrm{F}_{2}$, while the strata of the lowest thickness are distributed in three spots, the southeast, the northeast and near boundary fault $F_{1}$. (ii) The sandstone is thickest in area $\mathrm{G}$ and a small central area, and thinnest predominantly in the southeast. (iii) High sand content areas include part in the southeast and the majority of the north including G. Therefore it can be concluded that, during the deposition of the LST in Sequence III, G' was deemed the major sedimentary provenance.

TST (Fig. 7e) (i) Both the strata thickness and the sandstone thickness contour maps show similar distribution patterns, where the highest values are observed in the areas of $\mathrm{H}$ and $\mathrm{I}$, and the lowest are along the eastern boundary. (ii) Highest sand contents are also found in $\mathrm{H}$ and I besides an area next to boundary fault $\mathrm{F}_{2}$, while the lowest is in a small area of the middle west. So we assumed two major sedimentary provenances, H' and I', existed during the deposition of TST in Sequence III.

$H S T$ (Fig. 7f) (i) High strata thickness is found two places next to boundary fault $F_{2}$, the one in the middle is distributed in a fan shape. Lowest values are observed in two places near the boundary fault $\mathrm{F}_{1}$. (ii) The distribution 

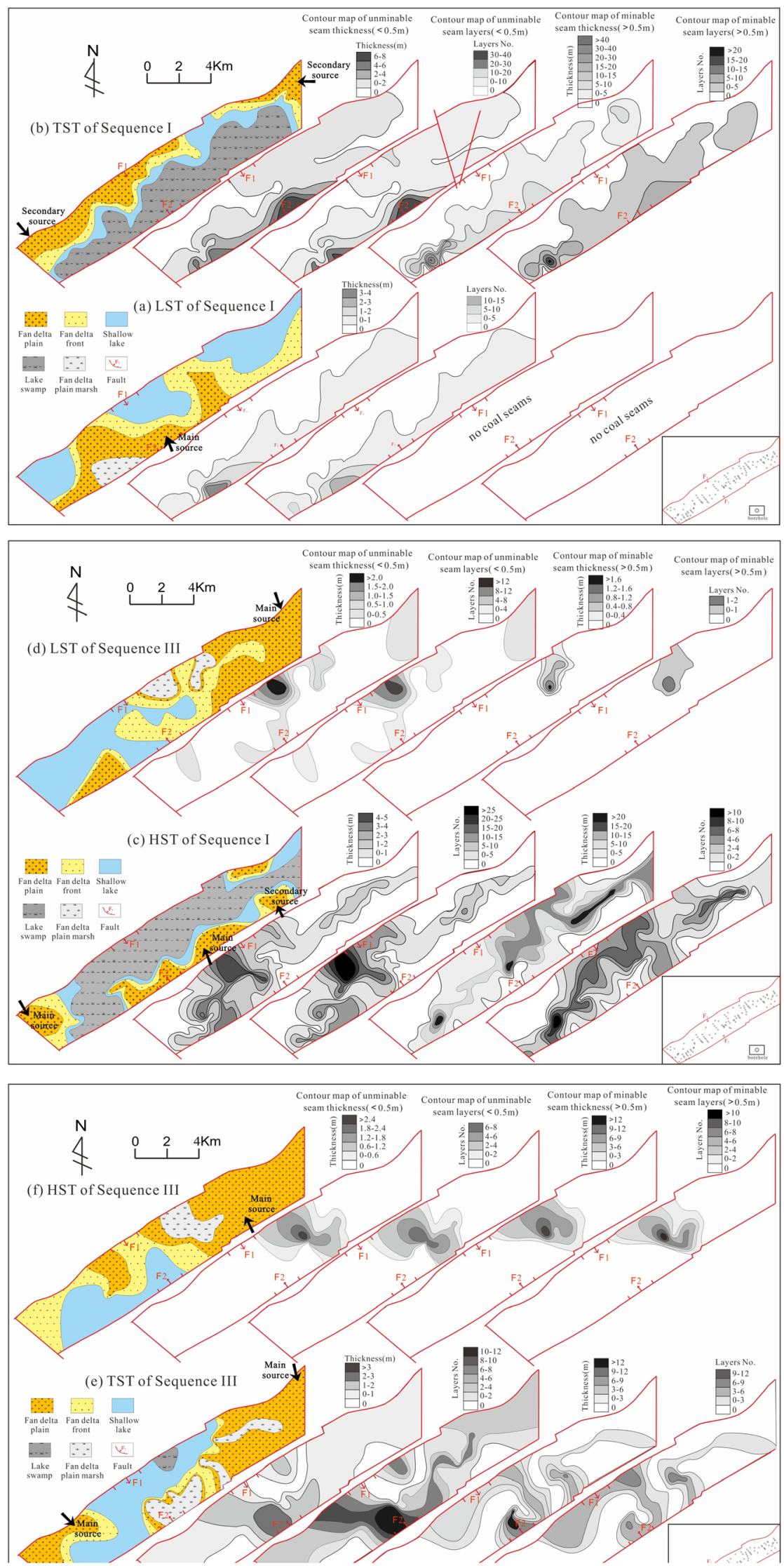
4Fig. 9 Distribution of the sedimentary facies, thickness and layers of coal seams of the LST $\mathbf{a}$ and the TST $\mathbf{b}$ in Sequence I $\mathbf{c}$ in Sequence I and the LST $\mathbf{d}$ in Sequence $\mathbf{e}$ and the HST $\mathbf{f}$ in Sequence III

of sandstone thickness follows a very similar pattern. (iii) Two areas of high sand content exist, one close to the middle west and the other in the vast north. The lowest sand content is located in the southeast. This suggests that sedimentary provenance J' existed during the deposition of HST in Sequence III.

\subsubsection{Distribution of coal seams}

The Meihe Basin is a fault basin with widely distributed coal seams. In this particular basin, coal seams of $0.5 \mathrm{~m}$ thickness and above are considered economically minable. In this section we put forth our study results of both minable and unminable coal seams in relation with their cumulative thickness, layering, vertical distribution (Fig. 8) and planar distribution (Fig. 9) in various system tracts of different sequences (Table 2). Furthermore, we studied the relationship between the distribution of coal seams and sedimentary environments.

\section{(1) Sequence I (The LCM)}

LST The coal seams developed in the LST of Sequence I are unminable. In the vertical profile, a few discontinuous thin coal seams are developed of fan delta plain marsh and distributed more widely in the southeast than the northwest (Fig. 8). Statistics from 134 wells show that unminable coal seams have a wide distribution with a total thickness of 0.08-3.14 $\mathrm{m}$ and up to 14 layers (Table 2). The thickness of a single coal seam is between $0.06 \mathrm{~m}$ and $0.49 \mathrm{~m}$ with a median of $0.19 \mathrm{~m}$ (Table 2). The thickness and number of layers both decrease from the northeast (close to the boundary fault $\mathrm{F}_{2}$ ) to the northwest (close to boundary fault $\mathrm{F}_{1}$ ). By synthesizing the contour maps of strata thickness, sandstone thickness and sand content, a palaeogeography and lithofacies map was produced. As shown on the map, the fan delta facies consist primarily of fan delta plain, fan delta front and shallow lake subfacies that developed from south to north. The shallow lacustrine sediments are mainly distributed in areas close to boundary fault $F_{1}$ (Fig. 9a). By overlapping the contour maps of coal thickness and layers with others, it can be concluded that the discovered coal seams are mainly developed in the fan delta plain marsh of medium strata thickness and low sand content (Fig. 7a). Coals accumulated in the fan delta plain are easily affected by sediment supply and channel migration, therefore many layers of unstable thin coal seams formed, and cost wise, they are unminable.

TST The coal seams of the TST in Sequence I have a wider distribution compared to the LST. They appear at the bottom as discontinuous and thin beds but gradually get thicker and more continuous near the top (Fig. 8). Statistics show that the minable coal seams are mainly distributed in the northwest, southeast and northeastern (Fig. 9b). The coal seams have up to 34 layers with a total thickness of 0.04-7.55 m, while the thickness of a single coal seam is between $0.04 \mathrm{~m}$ and $0.49 \mathrm{~m}$ with a median value of $0.22 \mathrm{~m}$ (Table 2). Coal seams are mainly distributed in the southeast, thinning out to the north. The sediments of the fan delta plain and fan delta front facies were mainly deposited in the northeast and west. Compared to the LST, the fan delta of TST features a narrower distribution. From map overlapping, it is known that the coal seams in TST were mainly developed in the lake swamp facies of large strata thickness and low sand content (Fig. 7b). Distal to the sediment source, the lake swamp environment is hardly influenced by waves or channel migration and thus appears

Table 2 Statistical results of layers and thickness of coal seams in LST, TST and HST of sequence I and sequence III

\begin{tabular}{|c|c|c|c|c|c|c|c|}
\hline \multirow[t]{2}{*}{ Coal property } & \multirow[t]{2}{*}{ Thickness/layer } & \multicolumn{3}{|c|}{ Sequence I } & \multicolumn{3}{|c|}{ Sequence III } \\
\hline & & LST & TST & HST & LST & TST & HST \\
\hline \multirow{4}{*}{$\begin{array}{l}\text { Commercial coal seams } \\
\qquad(>0.5 \mathrm{~m})\end{array}$} & Total thickness/single well (m) & - & $0.52-41.54$ & $0.84-45.19$ & $1.67-1.93$ & $0.5-15.06$ & $0.61-14.83$ \\
\hline & Layers/single well & - & $1-21$ & $1-14$ & $1-2$ & $1-8$ & $1-12$ \\
\hline & Thickness/single layer (m) & - & $0.5-6.98$ & $0.5-25.08$ & $0.73-1.93$ & $0.5-7.58$ & $0.52-5.71$ \\
\hline & $\begin{array}{l}\text { Average thickness/single layer } \\
(\mathrm{m})\end{array}$ & - & 1.45 & 2.46 & 1.2 & 1.24 & 1.31 \\
\hline \multirow{4}{*}{$\begin{array}{l}\text { Unminable coal seams } \\
\qquad(<0.5 \mathrm{~m})\end{array}$} & Total thickness/single well (m) & $0.08-3.14$ & $0.04-7.55$ & $0.15-4.88$ & $0.17-2.27$ & $0.13-2.98$ & $0.23-2.42$ \\
\hline & Layers/single well & $1-14$ & $1-34$ & $1-28$ & $1-13$ & $1-10$ & $1-8$ \\
\hline & Thickness/single layer (m) & $0.06-0.49$ & $0.04-0.49$ & $0.03-0.49$ & $0.04-0.48$ & $0.04-0.49$ & $0.07-0.48$ \\
\hline & $\begin{array}{l}\text { Average thickness/single layer } \\
\text { (m) }\end{array}$ & 0.19 & 0.22 & 0.21 & 0.25 & 0.27 & 0.27 \\
\hline
\end{tabular}


in large thicknesses and stable distribution. Among all the discovered minable coal seams of the Meihe Basin, those from the TST in Sequence I were formed the earliest.

HST Coal seams in HST tend to migrate to the northwest. Minable coal seams are mainly accumulated in the northwest and northeast (Fig. 9c). Statistics show that the coal seams have up to 14 layers with a total thickness up to $45.19 \mathrm{~m}$. The thickness of a single coal seam is between $0.5 \mathrm{~m}$ and $25.08 \mathrm{~m}$ with a median value of $2.46 \mathrm{~m}$. The unminable coal seams are mainly situated in the southwest of up to 28 layers, $0.15-4.88 \mathrm{~m}$ total thickness and $0.03 \mathrm{~m}$ $0.49 \mathrm{~m}$ single layer thickness (with a median of $0.21 \mathrm{~m}$ ) (Table 2). The fan delta sediments were mostly deposited close to boundary fault $F_{2}$. Lake swamp is the main depositional environment for coal seams that are distributed predominantly in the north close to boundary fault $F_{1}$ (Fig. 9c). Due to the distance, the fan delta sand body exerted little impact on the in situ accumulation of coals. Therefore these coal seams are characterized with large thickness and predictable distribution and hence greater economic value. In the vertical section, coal seams are thicker than in the TST, especially in the upper section. At the top of HST, the coal seams are the thickest and most continuous. During its deposition, the 12th coal seam, which has the highest commercial value, was formed (Fig. 8).

In summary, during the deposition of Sequence I, fan delta plain marsh and lake swamp are the main depositional environments for coals. The fan delta plain marsh is mainly distributed in the LST while the lake swamp is found in both TST and HST. In the sedimentary sequence of LSTTST-HST, the shallow lake facies are narrow and coal seams become more predominant. The coal-accumulating environments shifted from fan delta plain marsh to lake swamp facies. The TST is the earliest formation that contains minable coal seams, and more importantly, the HST bears coal seams of the highest commercial value in the study area.

\section{(2) Sequence III (the UCM)}

LST Minable coal seams in the LST of Sequence III are distributed in limited areas of the north. They have a total thickness of 1.67-1.93 m and consist of only one or two layers with $0.73-1.93 \mathrm{~m}$ thickness each (median $1.2 \mathrm{~m}$ ) (Table 2). Unminabe coal seams are mainly distributed in the northwest of up to 13 layers, $0.17-2.27 \mathrm{~m}$ total thickness, and $0.04-0.48 \mathrm{~m}$ (median $0.25 \mathrm{~m}$ ) single layer thickness. Fan delta was the main depositional environment and their sediments cover more than half of the study area. Besides, shallow lacustrine sediments are mainly distributed in the southwest. It can be deduced from map overlapping that the fan delta plain marsh is the main coal deposition environment (Table 1), but these coal seams are considered unminable with features of thin beds, discontinuous distribution and large numbers of layers.

TST Compared to LST, coal seams deposited in the fan delta plain marsh of TST are more widely distributed. Generally speaking, however, these coal seams are thin and discontinuous. Across the entire vertical section, relatively continuous single coal seams are developed (Fig. 8). The minable coal seams of LST are mainly in the central part of the study area (Fig. 9e) as they have up to 8 layers, 0.5-15.06 $\mathrm{m}$ total thickness, and $0.5-7.58 \mathrm{~m}$ (median $1.24 \mathrm{~m}$ ) single layer thickness. The unminable coal seams have a wider distribution (Fig. 9e). The unminable coal seams have up to 10 layers, $0.13-2.98 \mathrm{~m}$ total thickness, and $0.04-0.49 \mathrm{~m}$ (median $0.27 \mathrm{~m}$ ) single layer thickness (Table 2). Shallow lacustrine sediments are widely distributed in the central part, and a small portion of swamp is distributed close to boundary fault $F_{1}$. What's more, the fan delta sediments are widely distributed in the east and west, and fan delta plain marsh mainly located in the east and northeast is the main sedimentary facies for coal accumulation (Fig. 9e).

HST The coal seams are relatively thin and discontinuous, however in the bottom of the HST some relatively continuous thin coal seams are developed (Fig. 8). The coals are more narrowly distributed compared to the TST and are mainly limited to the central part of the study area (Fig. 9f). The minable coal seams have up to 12 layers with a total thickness range of $0.61-14.83 \mathrm{~m}$ and layer thickness of $0.52-5.71 \mathrm{~m}$ (median $1.31 \mathrm{~m}$ ). The unminable coal seams have up to 8 layers with $0.23-2.42 \mathrm{~m}$ total thickness and $0.07-0.48 \mathrm{~m}$ (average $0.27 \mathrm{~m}$ ) layer thickness (Table 2). Fan delta sediments are widely distributed in southwest. According to map overlapping, the coal seams were mainly accumulated in the fan delta plain marsh which have a deposition center close to boundary fault $F_{1}$ (Fig. 9f).

In a nutshell, compared to Sequence I, the coal seams developed in Sequence III are distributed in a narrower channel and with a smaller thickness. In addition, Sequence III fan delta sediments are more widely distributed but its shallow lacustrine sediments are the opposite. The coals were mainly formed in the fan delta plain marsh and therefore uneconomic for mining. Nevertheless, the TST and HST of Sequence III are considered the third and fourth accumulating stages of coals in the Meihe Basin.

\section{Discussion}

Previous studies have shown that the deposition of both Sequence I and Sequence III were in relatively stable structural settings (Wang et al. 2008). Coal of the Meihe Basin was mainly developed in flat depressions 


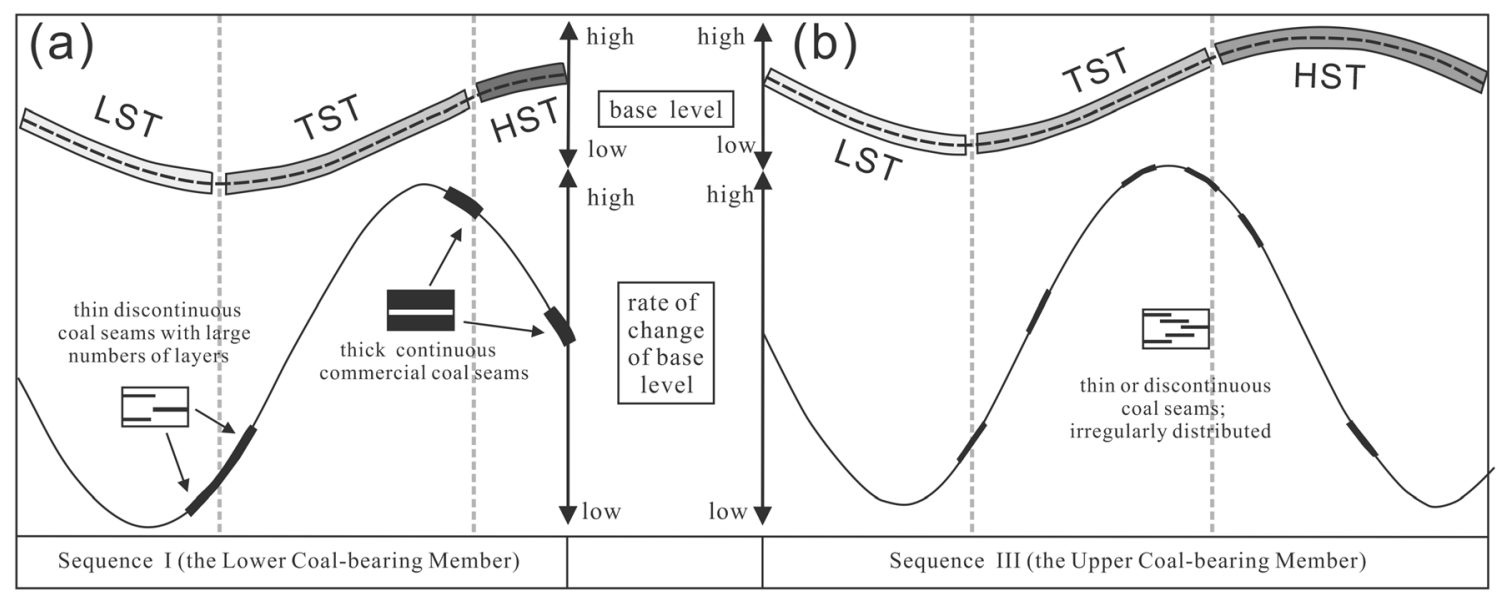

Fig. 10 Base level changes, rate of change of base level, and location of coal accumulations in Sequence I and Sequence III (Modified according to Bohacs and Suter (1997))

virtually free of terrigenous clastic sediment input or channel migration. Usually terrigenous plants grew fast in warm and humid paleoclimate, while peat accumulated rapidly in the freshwater environment. So there was sufficient organic matter input that led to coal accumulation (Bai et al. 2017). All of the above conditions together accounted for the formation of coal in the Meihe Basin.

The controlling factors of sequences are different in marine and non-marine basins (Liu et al. 2002). But in both environments, the accumulation of coal is controlled by the relative changes in base level and accommodation space. The theory of base-level cycles is applicable to both types of basins (Holz et al. 2002; Shao et al. 2003a). Of all the controlling factors, reducing environment is indispensable for peat accumulation. A relatively high and consistently rising lake level can effectively reduce the oxygen supply (Fasset 1986; Cheng and Yang 2001; Lv and Chen 2014). In warm and humid paleoenvironment where structural settings and reducing environment were stable, coal seams accumulated predominantly in the TST and HST of both sequences.

When LST was deposited, lake level fell and, as a result, its organic matter accommodation space was negatively affected. Since peat accumulation outran organic matter, the coal accumulation potential of LST was largely undermined. Additionally, developed fan delta sediments and frequently migrating channels are destructive for the formation of coal seams. Due to thin formation and discontinuous distribution, coal seams in LST are deemed unminable.

In the early stages of the TST, as surface level rose, lake accommodation space growth outran peat accumulation, thus the basin expanded. In the late stages, the rising of lake level slowed or even stopped, but the sediment supply continued, and therefore the lake eventually silted up. Since the sediment deposition rate was balanced with peat accumulation for a relatively long period of time without external disruption, thick, continuous, and widely distributed coal seams accumulated in Sequence I (Fig. 10a). However, in Sequence III the coal seams of the TST are thin, discontinuous and sparsely distributed. This is due to limited lacustrine sediment input and undeveloped lake swamp facies. On the contrary, fan delta sediments were widely distributed because of sufficient sediment supply.

During the deposition of the HST, lake level tended to be stable at first and then dropped. The fan delta underwent an alternating construction and destruction stage when the coal-bearing layers were extensively developed and mainly accumulated in the abandoned fan delta lobes. During the late stage of the HST, sediment progradation from the lakeshore occurred and the lake started to silt up. As the lake accommodation space grew at a balanced rate with peat accumulation, nice and thick coal seams from Sequence I were formed in lake swamp environments. These economically very attractive coal seams were also found in Sequence I (Fig. 10a) in the transitional environments between silted-up shallow lakes and abandoned fan delta lobes as favorable conditions were present for peat accumulation. In Sequence III, only a small number of discontinuous and thin coal seams were distributed in the Meihe Basin (Fig. 10b). This could be attributed to limited amount of lacustrine sediments and the influence of sediment supply or channel migration. Generally speaking, HST is similar to TST in terms of paleogeographic characteristics.

In summary, in a third-order sequence, coal accumulation varies with different sedimentary environments or stages. Therefore, the spatial distribution of coal-rich zones varies with time. In general, balance was somehow achieved between accommodation growth rate and peat accumulation in both TST and HST, as a result, nice and thick coal seams were widely distributed. But for other 
sedimentary environments and structural settings, different thicknesses and distribution patterns of coal seams were observed in Sequence I and Sequence III.

\section{Conclusions}

(1) Two of the three-third-order sequences developed in the Paleogene Meihe Formation of the Meihe Basin contain coal-bearing members, i.e., the LCM of Sequence I and the UCM of Sequence III. In both sequences, the system tracts of LST, TST and HST are developed.

(2) In LST of Sequence I, fan delta plain marsh is the main coal accumulating environment where coal seams are thin, discontinuous and therefore uneconomic for mining. While in TST and HST of Sequence I, lake swamp is the main sedimentary environment where coal seams are thick, continuous, widely distributed, and thus economically attractive for mining.

(3) Coal seams in Sequence III are all developed in fan delta plain marsh environments. In LST of Sequence III, coal seams are thin, sparsely distributed, hence of no economic value. Whereas in TST and HST of Sequence III, though more widely distributed, the coal seams are too thin to become economically minable.

(4) The late stages of TST and HST are most important for coal accumulation in the Meihe Basin. In the late stage of TST, lake accommodation growth rate was initially higher than peat accumulation as the water level kept rising. Then the rise gradually stopped, but the sediment supply still continued, so the lake eventually silted up. Since the sediment deposition rate was balanced with peat accumulation over a relatively long period of time without external disruption, thick, continuous, and widely distributed coal seams accumulated. During the deposition of the HST, the lake level was stable at first and then dropped. So when a long-term balanced state was somehow achieved between the growth rate of accommodating capacity and the rate of peat accumulation with little environmental disturbance, thick and economically minable coal seams accumulated.

Acknowledgements The research project was financially supported by the project of Geological Survey Project of No. DD20189607 and the Operating Expenses of Basic Scientific Research Project from Chinese Academy of Geological Sciences of No. JKY202012.

\section{Compliance with ethical standards}

Conflict of interest No potential conflict of interest was reported by the authors.

Open Access This article is licensed under a Creative Commons Attribution 4.0 International License, which permits use, sharing, adaptation, distribution and reproduction in any medium or format, as long as you give appropriate credit to the original author(s) and the source, provide a link to the Creative Commons licence, and indicate if changes were made. The images or other third party material in this article are included in the article's Creative Commons licence, unless indicated otherwise in a credit line to the material. If material is not included in the article's Creative Commons licence and your intended use is not permitted by statutory regulation or exceeds the permitted use, you will need to obtain permission directly from the copyright holder. To view a copy of this licence, visit http://creativecommons. org/licenses/by/4.0/.

\section{References}

Adabi M, Kakemem U, Sadeghi A (2016) Sedimentary facies, depositional environment, and sequence stratigraphy of Oligocene-Miocene shallow water carbonate from the Rig Mountain, Zagros basin (SW Iran). Carbonate Evaporite 31(1):69-85

Bai YY, Liu ZJ, Sun PC, Liu R, Hu XF, Zhao HQ, Xu YB (2014) Organic matter accumulation pattern of coal bearing layers in the lower part of Meihe Formation in Paleogene, Meihe Basin. J China Coal Soc 39(S2):458-464

Bai YY, Liu ZJ, Sun PC, Liu R, Hu XF, Zhou RJ, Xu YB, Wang JP (2017) Diverse sedimentary conditions during deposition of coal and oil shale from the Meihe Basin (Eocene, Ne China). J Sediment Res 87(10):1100-1120

Bohacs K, Suter J (1997) Sequence stratigraphic distribution ofcoaly rocks:fundamental controls and paralic examples. AAPG Bull 81(10):1612-1639

Buillit N, Lallier-Vergès E, Pradier B, Nicolas G (2002) Coal petrographic genetic units in deltaic-plain deposits of the Campanian Mesa Verde Group (New Mexico, USA). Int J Coal Geol 51(2):93-110

Cheng AG, Yang DY (2001) Analysis of coal accumulation system in China. China University of Mining and Technology: China National Administration of Coal Geology, Xuzhou, pp 1-110

Cross TA (1988) Controls on coal distribution in transgressiveregressive cycles, Upper Cretaceous, Western Interior, USA. Soc Econ Paleontol Mineral:371- 380

Diessel CF (1992) Coal-bearing depositional systems. Springer, Berlin, p 721

Diessel CF (2007) Utility of coal petrology for sequence-stratigraphic analysis. Int J Coal Geol 70(1):3-34

Diessel C, Boyd R, Wadsworth J, Leckie D, Chalmers G (2000) On balanced and unbalanced accommodation/peat accumulation ratios in the Cretaceous coals from Gates Formation, Western Canada, and their sequence-stratigraphic significance. Int J Coal Geol 43(1):143-186

Fasset JE (1986) The non-transferability of a Cretaceous coal model in the San Juan Basin of New Mexico and Colorado. Geol Soc Am Spec Pap 210:155-171

Feng ZZ (2004) Single factor analysis and multifactor comprehensive mapping method-reconstruction of quantitative lithofacies palaeogeography. J Palaeogeogr 6(1):3-19

Flint S, Aitken J, Hampson G (1995) Application of sequence stratigraphy to coal-bearing coastal plain successions: 
implications for the UK Coal Measures. Geological Society, London, Special Publications 82(1):1-16

GB/T 14506.30-2010. Methods for chemical analysis of silicate rocks-Part 30: Determination of 44 elements

GB/T 19145-2003. Determination of tatal organic carbon in sedcimentary rock

Holz M, Kalkreuth W, Banerjee I (2002) Sequence stratigraphy of paralic coal-bearing strata: an overview. Int $\mathrm{J}$ Coal Geol 48(3):147-179

Hu ST, Jing HL, Wu KP, Wang LW (1996a) The depositional systems and depositional system tracts in Meihe Basin. Coal Geol Explor 24:4-8

Hu ST, Kang XD, Wu KP, Wang YF (1996b) Sedimentary coal accumulating environment of Meihe Basin. Coal Geol China $8(2): 13-15$

Liu ZJ, Dong QS, Wang SM, Zhu JW, Guo W (2002) Introduction to continental sequence stratigraphy and application. Petroleum Industry Press, Beijing

Liu R, Liu ZJ, Hu XF, Sun PC, Bai YY, Zhao C (2015) Palaeogene sequences with sedimentary characteristics controlling the lacustrine oil shale of the Meihe Basin. Russ. J Pac Geol 34(4):3-18

Lv DW, Chen JT (2014) Depositional environments and sequence stratigraphy of the Late Carboniferous-Early Permian coalbearing successions (Shandong Province, China): sequence development in an epicontinental basin. J Asian Earth Sci 79:16-30

Olsen PE (1990) Tectonic, climatic, and biotic modulation of lacustrine ecosystems-examples from Newark Supergroup of eastern North America. Lacustrine basin exploration: case studies and modern analogs. AAPG Memoir 50:209-224

Opluštil S, Šimůnek Z, Zajíc J, Mencl V (2013) Climatic and biotic changes around the Carboniferous/Permian boundary recorded in the continental basins of the Czech Republic. Int J Coal Geol 119:114-151

Powell JW (1875) Exploration of the Colorado River of the Westand its tributaries Smithsonian Institute. DC, Washington, p 291

Ryer TA (1981) Deltaic coals of Ferron sandstone member of Mancos Shale: predictive model for Cretaceous coal-bearing strata of Western interior. AAPG Bull 65(11):2323-2340

Ryer TA (2009) Transgressive-regressive cycles and the occurrence of coal in some Upper Cretaceous strata of Utah, USA. In:
Rahmani RA, Flores RM (eds) Sedimentology of coal and coalbearing sequences. International Association of Sedimentologists, Special Publications 7, pp. 217-227

Shaley KW (1994) Alluvial architecture in a sequence stratigraphic framework. J Geol 102(2):105-109

Shanley KW, McCabe PJ (1994) Perspectives on the sequence stratigraphy of continental stratam. AAPG Bull 78(4):544-568

Shao LY, Zhang PF, Gayer RA, Chen JL, Dai SF (2003a) Coal in a carbonate sequence stratigraphic framework: the Upper Permian Heshan Formation in central Guangxi, southern China. J Geol Soc London 160(2):285-298

Shao LY, Zhang PF, Hilton J, Gayer R, Wang Y, Zhang C, Luo Z (2003b) Paleoenvironments and paleogeography of the Lower and lower Middle Jurassic coal Measures in the Turpan-Hami oil-prone coal basin, northwestern China. AAPG bull 87(2):335-355

Tian JC, Chen GW, Zhang X, Nie YS, Zhao Q, Wei DX (2006) Application of sedimentary geochemistry in the analysis of sequence stratigraphy. J Chendu Univ Technol (Sci Technol Ed) 33(1):30-35

Vail PR, Audermard F, Bowman SA, Eisner PN, Perez-Cruz G (1991) The stratigraphic signatures of tectonics, eustacy and sedimentology: an overview. In: Eisele G, Rieken W, Seilacher A (eds) Cycles and events in stratigraphy, Springer, Berlin, pp. 617-659

Van Wagoner JC, Mitchum RM, Campion KM, Rahmanian VD (1990) Siliciclastic sequence stratigraphy in well logs, cores, and outcrops: concepts for high-resolution correlation of time and facies. American Association of Petroleum Geologists, pp 30150

Wang JP (2012) Research on sedimentary characteristics of Meihe Formation of Paleogene in Meihe Basin. Master's Dissertation, Jilin University

Wang F, Li HJ, Wang DQ (2008) Meihe Basin coal-accumulating paleostructure analysis. Coal Geol China 20:13-15

Wu KP, Liu YX, Jing BZ, Lu YP (2008) Sedimentary coalaccumulating environment and prospecting coal prospect of Meihe Basin. Jilin Geol 27(3):24-33

Yao SQ (2012) The distribution characteristics of organic matter in sequence framework of Paleogene Meihe Formation in Meihe Basin. Master's Dissertation, Jilin University 